East Tennessee State University

Digital Commons @ East Tennessee State University

$10-5-2016$

\title{
Olanzapine for Chemotherapy-Induced Nausea and Vomiting
}

John B. Bossaer

East Tennessee State University, bossaer@etsu.edu

Follow this and additional works at: https://dc.etsu.edu/etsu-works

Part of the Oncology Commons, and the Pharmacy and Pharmaceutical Sciences Commons

\section{Citation Information}

Bossaer, John B.. 2016. Olanzapine for Chemotherapy-Induced Nausea and Vomiting. New England Journal of Medicine. Vol.375(14). 1395-1396. https://doi.org/10.1056/NEJMc1610341 ISSN: 0028-4793

This Article is brought to you for free and open access by the Faculty Works at Digital Commons @ East Tennessee State University. It has been accepted for inclusion in ETSU Faculty Works by an authorized administrator of Digital Commons@ East Tennessee State University. For more information, please contact digilib@etsu.edu. 


\section{Olanzapine for Chemotherapy-Induced Nausea and Vomiting}

\section{Copyright Statement}

From New England Journal of Medicine, John B. Bossaer, Olanzapine for Chemotherapy-Induced Nausea and Vomiting, Volume 375 No. 14, Page No. 1395-1396 Copyright (@ 2016 Massachusetts Medical Society. Reprinted with permission.

This Article is brought to you for free and open access by the Faculty Works at Digital Commons @ East Tennessee State University. It has been accepted for inclusion in ETSU Faculty Works by an authorized administrator of Digital Commons @ East Tennessee State University. For more information, please contact digilib@etsu.edu. 
East Tennessee State University

Digital Commons@ East Tennessee State University

ETSU Faculty Works

Faculty Works

$10-5-2016$

\section{Olanzapine for Chemotherapy-Induced Nausea and Vomiting}

John B. Bossaer

East Tennessee State University, bossaer@etsu.edu

Follow this and additional works at: https://dc.etsu.edu/etsu-works

Part of the Oncology Commons, and the Pharmacy and Pharmaceutical Sciences Commons

\section{Citation Information}

Bossaer, John B.. 2016. Olanzapine for Chemotherapy-Induced Nausea and Vomiting. New England Journal of Medicine. Vol.375(14). 1395-1396. https://doi.org/10.1056/NEJMc1610341 ISSN: 0028-4793

This Article is brought to you for free and open access by the Faculty Works at Digital Commons @ East Tennessee State University. It has been accepted for inclusion in ETSU Faculty Works by an authorized administrator of Digital Commons @ East Tennessee State University. For more information, please contact digilib@etsu.edu. 


\section{Olanzapine for Chemotherapy-Induced Nausea and Vomiting}

\section{Copyright Statement}

From New England Journal of Medicine, John B. Bossaer, Olanzapine for Chemotherapy-Induced Nausea and Vomiting, Volume 375 No. 14, Page No. 1395-1396 Copyright (C) 2016 Massachusetts Medical Society. Reprinted with permission. 
Somewhat reduced sensitivity to ticagrelor that is associated with greater platelet reactivity (i.e., a higher occurrence of high residual platelet reactivity during treatment) has been reported in patients older than 70 years of age, independent of sex, body-mass index, diabetes, cholesterol and fibrinogen levels, smoking, renal function, previous myocardial infarction, concomitant cardiovascular therapy, hemoglobin levels, and platelet count. ${ }^{1}$ Similarly, an age older than 70 years has been inversely associated with the probability of low platelet reactivity. ${ }^{2}$ Given the above-mentioned results of the SOCRATES trial, data stratification according to a 70-year age limit may reveal a clearer distinction. Regardless of either a 65-year or 70-year limit, the possible superiority of ticagrelor over aspirin in reducing cardiovascular risk among younger patients should be explored further.

Viktor Čulić, M.D., Ph.D.

University Hospital Center Split

Split, Croatia

viktor.culic@st.t-com.hr

No potential conflict of interest relevant to this letter was reported.

1. Verdoia $M$, Pergolini $P$, Rolla $R$, et al. Advanced age and high-residual platelet reactivity in patients receiving dual antiplatelet therapy with clopidogrel or ticagrelor. J Thromb Haemost 2016;14:57-64.

2. Alexopoulos D, Xanthopoulou I, Storey RF, et al. Platelet reactivity during ticagrelor maintenance therapy: a patient-level data meta-analysis. Am Heart J 2014;168:530-6.

DOI: 10.1056/NEJMc1610106

THE AUTHORS REPLY: As noted by Landman and Kleefstra, ticagrelor appeared more effective than aspirin in the subgroup of patients who had taken aspirin previously. Although this may relate to a greater effect of ticagrelor in patients who did not have a response to aspirin, it could also rep- resent a benefit from ticagrelor on a background of residual antiplatelet effects from aspirin, which persist for more than a week after a dose. A more detailed analysis is planned.

PPIs were used at baseline by 585 of 6549 patients $(8.9 \%)$ in the ticagrelor group and by 613 of 6581 patients $(9.3 \%)$ in the aspirin group. There were no significant differences in major hemorrhage or in major and minor hemorrhage combined according to treatment in either PPI subgroup. Thus, the data do not support the use of aspirin by those taking a PPI, though the statistical power is limited.

As noted by Čulić, we originally evaluated the effect of treatment among three age strata on the basis of an analysis plan that was established a priori, and ticagrelor was nominally superior to aspirin in patients younger than 65 years of age, with a trend toward significance in patients 65 to 75 years of age. When the population is stratified at 70 years of age, among those 70 years of age or younger the primary outcome event occurred in $6.2 \%$ of those assigned to ticagrelor and $7.1 \%$ of those assigned to aspirin $(\mathrm{P}=0.09)$. Among those older than 70 years of age, event rates were $7.8 \%$ with ticagrelor and $8.2 \%$ with aspirin $(\mathrm{P}=0.45)$. The interaction between age group and treatment was not significant $(\mathrm{P}=0.63)$. Thus, we cannot confirm that age has an effect when dichotomized at 70 years.

S. Claiborne Johnston, M.D., Ph.D.

Dell Medical School

Austin, TX

Pierre Amarenco, M.D.

Bichat University Hospital and Medical School Paris, France

Since publication of their article, the authors report no further potential conflict of interest.

DOI: 10.1056/NEJMc1610106

\section{Olanzapine for Chemotherapy-Induced Nausea and Vomiting}

TO THE EDITOR: Navari and colleagues (July 14 issue) ${ }^{1}$ report on the use of olanzapine for the prevention of chemotherapy-induced nausea and vomiting. The methods allowed for real-world use of neurokinin-1 $\left(\mathrm{NK}_{1}\right)$-receptor antagonists, either oral aprepitant or intravenous fosaprepitant. Although the dosing of dexamethasone is consistent on days 1 and 2 between agents, it should differ between an oral dose of $8 \mathrm{mg}$ daily on days 3 and 4 in patients receiving aprepitant and an oral dose of $8 \mathrm{mg}$ twice daily on days 3 and 4 in those receiving fosaprepitant. ${ }^{2}$ Because fosaprepitant is given only on day 1 , the drug interaction with dexamethasone is absent on days 3 and 4, thus necessitating a higher dexamethasone dose. Per the study protocol (available with the full text 
of the article at NEJM.org), the dexamethasone dosing was the same regardless of which $\mathrm{NK}_{1}$-receptor antagonist was used. This approach would not have affected the results for the evaluation period of 0 to 24 hours but in effect resulted in a substandard comparator group for the evaluation of delayed nausea and vomiting (in the period of 0 to 120 hours). Anecdotally, this discrepancy in dexamethasone dosing occurs commonly in community practices, and it is important for clinicians to remain diligent with regard to the dosing of supportive care medications in patients receiving chemotherapy.

John B. Bossaer, Pharm.D.

East Tennessee State University

Johnson City, TN

bossaer@etsu.edu

No potential conflict of interest relevant to this letter was reported.

1. Navari RM, Qin R, Ruddy KJ, et al. Olanzapine for the prevention of chemotherapy-induced nausea and vomiting. N Engl J Med 2016;375:134-42.

2. Emend (fosaprepitant dimeglumine). Whitehouse Station, NJ; Merck, February 2016 (package insert) (https://www.merck .com/product/usa/pi_circulars/e/emend_iv/emend_iv_pi.pdf).

DOI: 10.1056/NEJMc161034]

THE AUTHORS REPLY: Bossaer raises the issue of using a higher dose of dexamethasone on days 3 and 4 after chemotherapy than on days 1 and 2 when intravenous fosaprepitant is used in lieu of 3 days of oral aprepitant. In a trial by Grunberg et al. ${ }^{1}$ in which intravenous fosaprepitant was compared with 3 days of oral aprepitant and shown to be noninferior for the control of chemotherapyinduced nausea and vomiting in the delayed evaluation period and the overall period, dexamethasone was given in higher doses on days 3 and 4 than on days 1 and 2 in the fosaprepitant group. However, a subgroup analysis in our trial of olanzapine showed no difference in results among patients who received fosaprepitant and those who received aprepitant. In addition, recent studies have suggested that multiple days of dexamethasone may not be necessary for the prevention of chemotherapy-induced nausea and vomiting. ${ }^{2,3}$

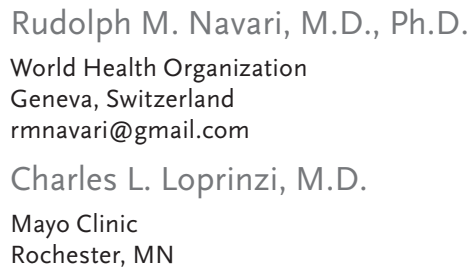

Since publication of their article, the authors report no further potential conflict of interest.

1. Grunberg S, Chua D, Maru A, et al. Single-dose fosaprepitant for the prevention of chemotherapy-induced nausea and vomiting associated with cisplatin therapy: randomized, doubleblind study protocol — EASE. J Clin Oncol 2011;29:1495-501. 2. Celio L, Bonizzoni E, De Braud F, Agustoni F, Aapro M. Should clinicians always administer dexamethasone beyond 24 $\mathrm{h}$ after chemotherapy to control delayed nausea and vomiting caused by moderately emetogenic regimens? Insight from the re-evaluation of two randomized studies. Support Care Cancer 2016;24:1025-34.

3. Matsuzaki K, Ito Y, Fukuda M, et al. Placebo-controlled phase III study comparing dexamethasone on day 1 to on day 1-3 with NK1 receptor antagonist and palonosetron in high emetogenic chemotherapy. J Clin Oncol 2016;34:Suppl:10019. abstract.

\section{State Regulations and Opioid Use among Disabled Adults}

TO THE EDITOR: Meara et al. (July 7 issue) ${ }^{1}$ conclude that state laws such as those supporting prescription-drug monitoring programs (PDMPs) do not reduce hazardous opioid use or nonfatal overdose. These conclusions may cause clinicians and policymakers to discount the value of PDMPs. In addition, the findings of the study diverge from those of other recent studies assessing the effect of PDMPs..$^{2-4}$ Patrick et al., using a more rigorous design to account for the specific features of PDMPs, found that these programs were associated with declines in deaths from opioid overdose. ${ }^{3}$ Bao et al., using a nationally representative sample - not only Medicare beneficiaries with disabilities - found a 30\% decline in the prescribing of Schedule II opioids after the implementation of PDMPs. ${ }^{4}$ The decision by Meara et al. to include multiple laws regarding controlled substances in a single analysis presupposes that each law within a category is identical. Categorizing laws as enacted or not enacted ignores heterogeneity across laws of the same type. It is the components of a law and the implementation and enforcement of those components that matter. The null findings of the study may be a by-product of these methodologic choices. Additional investigation is needed to further evaluate the effects of PDMPs and other state-level interventions. 